\title{
NOTES
}

\section{SHAREHOLDER ATTACK AGAINST STOCK OPTIONS FOR CORPORATE EXECUTIVES*}

A PUBLICLy held corporation may reward its executives by granting them options to purchase stock. ${ }^{1}$ In the ten years prior to 1950, grants of stock options were relatively rare. ${ }^{2}$ In the face of revenue laws that generally taxed option profits in the same manner as ordinary income, ${ }^{3}$ executives apparently preferred cash payments or other forms of compensation rather than possibly speculative option gains and equity in the corporation. ${ }^{4}$ But recent additions to the Internal Revenue Code and Salary Stabilization Board Regulations have catapulted the stock option into prominence. Section $130 \mathrm{~A}$ of the Code ${ }^{5}$ permits executives to postpone the tax on profits from "restricted" stock options "

*Kerbs v. California Eastern Airways, Inc., 90 A.2d 652, rehearing denticd, 91 A.2d 62 (Del. Sup. Ct. 1952) ; Gottlieb v. Heyden Chemical Corp., 90 A.2d 660, limitcd relicaring granted, 91 A.2d 57 (Del. Sup. C.. 1952), adherence on rehearing, 21 U.S.L. WEEK 2230 (Del. Sup. Ct. Nov. 14, 1952).

1. Executives stand to profit to the extent that the market price of the company's shares rises above the option price. Baker, Stock Options for Exectitives, 19 HaRv. Bus. REv. 106, 115 (1940) (data on large executive profits under stock option plans from 19351939). Stock options are used primarily by publicly held corporations, since options are valuable only where stock is traded.

2. Fetter \& Johnson, Compensation and Incentives for Industrial Executtues 95 (1952) (only 2 of 50 companies studied had stock options between 1945 and 1949). From 1928 to 1938 about 25-35\% of listed corporations adopted stock option plans. Baker, supra note 1 , at 107,121 . While companies in financial straits often used options during this period to employ high-priced executives without large cash outlay, many prosperous companies also gave options as "a token of appreciation." Id. at 109-110.

3. Prior to 1946, option profits were taxed at regular income rates when "intended" as a substitute for salary, while profits from options "intended" solely to give cmployees a proprietary interest in the company were taxed at capital gains rates. From 1946 to 1950, the Commissioner attempted, with limited success, to tax all option profits at regular rates. For a full survey of tax aspects, see Washington \& Rothschild, Compensating the Corporate Executive 129-148 (2d ed. 1951) (hereinafter cited as Wasuington \& RoTrscrind); Alexander, Employee Stock Options and the 1950 Revemuc Act, 6 TAx L. Rev. 165 (1951); Lyon, Employee Stock Option under the Internal Revenue Code of 1950, 51 CoL. L. REv. 1, 4-17 (1951).

4. The relative tax advantages of stock options and other forms of deferred compensation are discussed in Business Reports, Inc., Executive Pay Prans (1951); Conference Board Management Record, Increasing Executive Take-Home PaY (1951) ; Mahon, Corporate Tax Planting to Get Minimum Tax Liability for Extculives and Shareholders, 92 J. Accountancy 582 (1951).

5. INT. Rev. CoDE $\S 130$ A.

6. For an option to qualify as a "restricted" stock option, the option price must be at least $85 \%$ of the market value of the stock at time of grant. Further, the employee's 
until disposal of the stock purchased under the option, and, in some cases, provides capital gains rather than ordinary income treatment of option profits. ${ }^{7}$ At the same time, the Salary Stabilization Board has exempted from the salary freeze stock options qualifying for capital gains treatment under $130 \mathrm{~A} .{ }^{8}$. As a result, over 300 corporations have adopted stock option plans for executives in the past two years. ${ }^{9}$ The flood of options has been accompanied by the appearance of stockholder suits attempting to check their issuance on the theory that they constitute "gifts of corporate assets."10

option must be non-transferable and exercised during employment or three months thereafter. Stock acquired must not be sold by the optionee until two years after the option is granted and six months after the option is exercised. And the optionee must hold less than ten percent of the voting power of the granting corporation. I:r. REw. CONE $\$ 130$ A(d). For discussion see sources cited note 3 sipra.

7. If the option price is between $55 \%$ and $95 \%$ of market price at the time of the option grant, the executive is taxed at regular income rates when the stocl: acquired under the option is disposed of, but then only on the spread between option price and market price at time of grant. If, however, the option price is at least $95 \%$ of market value at time of grant, there is no tax on the spread; and the executive pays only capital gains rates on the difference between the value of the stock when the option was exercised and its value when the executive disposes of it. ImT. REv. CONZ $\$ 130 A$ (b). For accounting mechanics, see Accounting Rescarch Bulletiss No. 37, Accoustisg for Compensation in the Form of Stock Options, \$7 J. Accountancy 3S-41 (1949).

For criticism of $\S 130 \mathrm{~A}$ as "handouts ... to a special few taxpayers" (corporate executives), see Griswold, The Blessings of Taxation: Reccnt Trends in the La:v of Federal Taxation, 36 A.B.A.J. 999, 1057 (1950) ; Lyon, stpra note 3, at 1, 58. But see Sert. Rep. No. 2375, S1st Cong., 2nd Sess. 59 (1950).

8. SSB General Salary Stabilization Regulation No. 4 (rev.), 17 Fzo. REg. 3924 (1952). Stock option plans were included in the salary freeze during World War II. WASHINGTON \& ROTHSCHILD 296-322 (history of salary stabilization policies from 19421951). For rationale of present Salary Stabilization Board policy, see Reforr of Spectar Panel to Salary Stabilization Board, Stock Options amd Stock Purcinase Plarss (Oct. 23, 1951).

9. Wall Street Journal, August 6, 1952, p. 1, col. 5. See also Míckuser \& Co., Srozis Options as AN INCENTIVE FOR ExECUTIVES (1952) (1 out of 6 companies on the New York Stock Exchange have stock option plans). Securing of tax benefits for executives seems to be the principal stimulus for many post-1950 option plans. See, c.g., advice to corporations by management consultants in Patton, Who Should Get Slocl: Oplions? 30 Personnet J. 417, 424 (1952); Mchnnsey \& Co., op. cit. supro, at 2. Mlany proxy statements, while indicating options were granted pursuant to $\$ 130 \mathrm{~A}$, give no other rason for the grant of the plan. NICB, Executre Stock Ownershis Plaws 35, 39, 54, 55, 70 (1951). Despite widespread use of stock options to effectuate tar savings for esceutives, it is not clear that such savings do stimulate managerial efficiency. See FETrER \& Jou::soN, op. cit. supra note 2 , at $37-48$ (high surtax rates have probably not drained manzgerial efficiency).

10. E.g., minority shareholder suits are now pending against the option plans of U.S. Steel, Standard Oil of New Jersey, Commercial Investment Trust, American Airlines and other corporations. Communication to the YALE L.tw Jourwal from Messrs. Fultun, Walter, and Halley, dated September 17, 1952, in Yale Law Library. 
In two recent cases before the Delaware Supreme Court, Kerbs v. California Eastern Airways, Inc. ${ }^{11}$ and Gottlieb v. Heyden Chemical Corporation, ${ }^{12}$ individual stockholders sued to enjoin the operation of option plans. Boards of directors of the defendant corporations had voted stock options to themselves and to other executives. Eastern Airways claimed that it sought to retain key men through increases in compensation, ${ }^{13}$ while the alleged pur* pose of the Heyden Chemical Corporation option plan was to stimulate executives' incentive by providing them with a proprietary interest in the corporation. ${ }^{14}$ The option plans were submitted to stockholders for approval and a majority of the stockholders ratified. Shortly after ratification of the Eastern Airways options the market price of Eastern Airways stock doubled. ${ }^{15}$

In both cases the court pointed out that the primary issue before it wats the existence of "consideration" sufficient to support the grant of the option to the executive. ${ }^{16}$ Eastern Airways' option program, designed to retain key men, was held to lack necessary consideration, since the plan permitted options to be exercised immediately or within a short time after termination of employment and, consequently, did not adequately insure that executives would remain with the company. ${ }^{17}$ Judgment for plaintiff was rendered. In the Heyden Chemical case, the court held deficient as a matter of law a plan whose sole objective was to encourage stock ownership. ${ }^{18}$ The court denied

11. 90 A.2d 652 (Del. Sup. Ct. 1952), reversing 83 A.2d 473 (Del. Ch. 1951).

12. 90 A.2d 660, limited rehearing granted, 91 A.2d 57 (Del. Sup. Ct. 1952), adherence on rehearing, 21 U.S.L. WEeK 2230 (Del. Sup. Ct. Nov. 14, 1952), reversing 83 A.2d 595 (Del. Ch. 1951).

13. Brief for Appellee, pp. 31-3, Kerbs v. California Eastern Airways, Inc., 90 A.2d 652 (Del. Sup. Ct. 1952).

14. Brief for Appellee, p. 7, Gottlieb v. Heyden Chemical Corp., 90 A.2d 660 (Dd. Sup. Ct. 1952).

15. The facts of the two cases are set out in Kerbs v. California Eastern Airways, Inc., 90 A.2d 652, 654-5 (Del. Sup. Ct. 1952), and Gottlieb v. Heyden Chemical Corp., 90 A.2d 660, 661-3 (Del. Sup. Ct. 1952).

16. Gottlieb v. Heyden Chemical Corp., 90 A.2d 660, 664 (Del. Sup. Ct. 1952) ; Kerbs v. California Eastern Airways, Inc., 90 A.2d 652, 656 (Del. Sup. Ct. 1952).

17. Id. at 656-7. The court, on grounds that the tax law is "insecure," rejected appellee's argument that inducement to qualify for $\$ 130 \mathrm{~A}$ benefits would keep exccutives with the coporation. Ibid. The court's position is ostensibly sound since there is strong organized pressure to repeal $\$ 130$ A. See, e.g., C.I.O. PAMPerLet No. 190, For a Falk TAX PoLIcy (1951). And it is possible, though questionable, that changes can apply retroactively where parties have relied on the prior law. Compare Milliken v. United States, 283 U.S. 15 (1931) (retroactive application valid where taxpayer knew at time of reliance that tax changes were contemplated by Congress), with Nichols v. Coolidge, 274 U.S. 531 (1927) (retroactive application invalid where reliance on prior law).

18. Gottlieb v. Heyden Chemical Corp., 90 A.2d 660, 664 (Del. Sup. Ct. 1952). The Heyden Chemical Corporation plan may have been called "proprietary" to escape the need for Salary Stabilization Board approval, since, under Board Regulation 4, options to increase incentive and encourage stock ownership can be granted without Board 
motion for summary judgment, however, and remanded the case to the trial court with instructions to take further evidence on the plan's objective ${ }^{10}$ and to consider whether the value of the options was reasonably geared to the services the plan insured. ${ }^{0}$ On petition for rehearing, the court also noted that a presumption of validity would attach to the directors' actions in all situations except where directors vote themselves options without stoclholder ratification. ${ }^{21}$

The "consideration" doctrine as typically stated by the Delaware court 2 affords little chance for shareholder victories in future suits. To conform to the Eastern Airaiays holding, requiring assurance that the option plan's objectives will be realized, corporations need only tie up the services of executives. ${ }^{23}$ Assurances such as one-year employment contracts, installment options contingent on continued employment, and covenants not to compete

approval, while plans intended to constitute compensation require approval. With the Delaware court's requirement that option plans contain provisos to retain executives, the Board may consider these plans "compensatory." Consequently, corporations, to aroid criminal prosecution, would do well to secure Board approval of plans with retention provisos. Alternatively, the corporation may choose to bring its stocls option plan within other exceptions to salary freeze regulations by (1) insuring that executives do not dispose of "option stock" within periods specified in Regulation 4; or (2) granting options as "increased compensation" for merit and length of service, "new and changed position," promotion, or permissible groups. For collected regulations and discussion see P-H CORP. SERv. $\uparrow 20,979$ (1952); Washington \& Rótraschilo 315-19.

19. Gottlieb v. Heyden Chemical Corp., 90 A.2d 660, 664 (Del. Sup. Ct. 1952).

20. Id. at 665, modified, 91 A.2d 57, 59 (Del. Sup. Ct. 1952).

21. Id. at 58. For discussion of the presumption, see 3 Fletcrer, Cyczorenrs of

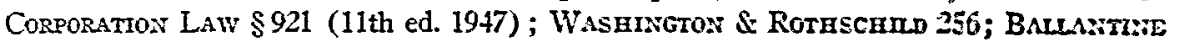
oN CoRporations $\$ 70$ (2d ed. 1946).

The court granted petition for rehearing on the single issue of whether a Delaware statute, making directors' judgment conclusive about the value of consideration for stods, applies to stock option plans, Gottlieb v. Heyden Chemical Corp., 91 A.2d 57, 60 (Del. Sug. Ct. 1952), and decided that the statute did not apply. Gottlieb v. Heyden Chemical Corp., 21 U.S.L. WeEr 2230 (Del. Sup. Ct. Nov. 14, 1952). For problems raised in applying this type of statute to stock options, see Comment, 47 Mrсн. L. Rer. 1179, 1185 (1949).

22. The Delaware "consideration" requirement is generally followed elsewhere. See, e.g., McQuillen v. National Cash Register Co., 112 F.2d 877, 834 (4th Cir. 1940); Holthusen v. Budd Mfg. Co., 52 F. Supp. 125 (E.D. Pa. 1943). But New York courts dispense with the consideration requirement when the option price of shares is above the marliet price in the period between the grant of the option and the commencement of the suit. Abrams v. Allen, 36 N.Y.S.2d 170 (Sup. Ct. 1942), aff'd mom, 266 App. Div. 835, 42 N.Y.S.2d 641 (1st Dep't 1943). This rule, based on the belief that such options are valueless, overlooks the value that "stems from the optionee's assurance of participation, share for share, in any increase in the market value of any security, without investment in it and without the risk of loss." Comment, 49 COL. L. Rev. 232, 235 (1949).

23. Wall Street Journal, August 6, 1952, p. 1, col. 5; P-H Corporation News, September 22, 1952, p. 1. See also communication to Yale LAW Jourral from Arthur G. Logan, counsel for shareholder in the Eastern Airuays case, dated Sept. 2, 1952, in Yale Law Library, indicating defendant's plans to amend option grant. For indications 
have long been considered sufficient. ${ }^{24}$ And since courts are willing to infer from the existence of a legal obligation to remain with a corporation that an option plan seeks tó retain executives, the Heyden Chomical requirement of a legitimate objective for the plan becomes academic. ${ }^{25}$ Finally, insistence that the value of options be reasonably related to the executive services to be rendered is generally a meaningless pronouncement. Courts state that they are unable to gauge the worth of executive services. ${ }^{26}$ And if suit is brought to enjoin the option plan prior to its operation, the value of the unexercised option is also speculative. ${ }^{27}$ In the past, the court's inability to evaluate in such situations has almost always resulted in judgment for the corporation through recourse to the "proper business judgment rule," which establishes a presumption in favor of the validity of the plan. ${ }^{28}$ On the other hand, after

of the large number of post-1950 plans that will probably be invalid unless amended to conform to the Eastern Airways holding, see NICB, Executrve Stock Ownersurn Plans, Table 16, Append. A and B (1951). For legal problems in amending a running employment contract, see WASHINGTON \& Rothschild 269.

24. See, e.g., Holthusen v. Budd Mfg. Co., 53 F. Supp. 488, 489 (E.D. Pa. 1943) (1-year employment contract with stock aption); Sandler v. Schenley Industries, Inc., 79 A.2d 606, 609 (Del. Ch. 1951) (installment option) ; WAsmincron \& Roruscurid 33, 182, 205-06 (pension plans with covenant against competition). And see Kaufman v. Shoenberg, 21 U.S.L. WeEK 2194 (Del. Ch. Oct. 21, 1952).

Court insistence on tying up executive services does insure realization of the goal of retaining the executives. However, where an option plan seeks to increase incentive, mere tying up of services is no guarantee of increased executive effort. Consequently, where incentive plans are involved, courts should insist on making the exercise of the option conltingent on rising profits or dividends. But see Kaufman v. Shoenberg, 21 U.S.L. WEEK 2194 (De1. Ch. Oct. 21, 1952). Several post-1950 plans satisfy this requirement. See NICB, EXecutive Stock Ownership Plans 17 (1951).

25. See, e.g., Holthusen v. Budd Mfg. Co., 53 F. Supp. 488, 490 (E.D. Pa. 1943). The legitimate objective recluirement also becomes academic when courts do not look behind the stated purpose of option plans, for the stated objective may often fail to reflect the actual purpose of the grant. See, e.g., Clamitz v. Thatcher Mfg. Co., 158 F.2d 687, 693 (2d Cir. 1947), cert. denied, 331 U.S. 825 (1947). See also Sanders, THE EFreCT of Taxation on Executives 129 (1951); Lyon, Employee Stock Options under the Internal Revenue Code of 1950, 51 Cor. L. Rev. 1, 10 (1951). However, it is clear that reward for past services does not constitute a legitimate objective for option plans. Holthusen v. Budd Mfg. Co., 52 F. Supp. 125, 129 (E.D. Pa. 1943). But reward for past services may be sufficient consideration for pensions and bonuses. WASHINGroN \& Rotriscumb 275-8. For exception to the "past services" rule, see BalLantine on CoRporations \$75 (2d ed. 1946).

26. See, e.g., Heller v. Boylan, 29 N.Y.S.2d 653, 669 (Sup. Ct. 1941), aff'd mem, 263 App. Div. 815, 32 N.Y.S.2d 131 (1st Dep't 1941) ; Baker, $A$ "Just Gauge" for E.rec1ltive Compensation, 22 Harv. Bus. Rev. 75 (1943). See also Washington, The Corporation Executive's Living Wage, 54 HARv. L. REv. 733, 769 (1941).

27. For discussion, see Wyles v. Campbell, 77 F. Supp. 343, 350 (D. Del. 1948).

28. See, e.g., Clamitz v. Thatcher Mfg. Co., 158 F.2d 687, 693 (2d Cir. 1947), ccrt. denied, 331 U.S. 825 (1947) ; Diamond v. Davis, 38 N.Y.S.2d 103, 115-116 (Sup. Ct. 1942), aff'd mem., 292 N.Y. 554, 54 N.E.2d 683 (1944). And see cases and discussion in WASHINGTON \& ROTHSCHILD 383-412. 
the option has been exercised, suits brought against executives to recover option profits do have the value of the option ascertained. But since executives have remained with the corporation in reliance on the option grant, courts again uphold the options except in the most blatant cases of abuse..$^{9}$

Legal doctrines other than "lack of consideration" also provide little opportunity to check the issuance of options. Pre-emptive rights tenets are of meager assistance since they do not give shareholders priority to subscribe to the treasury shares or original issue utilized in almost all option plans. ${ }^{20}$ And even where other shares are used, state statutory provisions may render pre-emptive rights nugatory. ${ }^{31}$ Stockholders may also attempt to prove "overreaching" by directors in the grant of an option. ${ }^{32}$ But, although stocliholders have raised the issue in cases where there was apparently a llagrant breach of fiduciary duty, the theory has never invalidated an option plan. ${ }^{23}$ And some courts are even willing to hold that a conceded breach of duty is "corrected" once stockholder ratification has taken place. ${ }^{34}$

29. For full discussion, see Comment, 49 CoL. L. Rev. 232, 236 (1949). Moreover, plaintiffs who bring suits against directors to recover option profits after ortions have been exercised may run afoul of prohibitive bonds required by several states in stod:holder "derivative" actions. For collection of statutes requiring bonds, sce Barratirn: ON CORPGRATIONS $\$ 157$ a (2d ed. 1946). On the other hand, suits brought against the curporation to enjoin commencement of option plans are apparently considered "individual" and not "derivative." Id. at 336.

30. Id. at $\$ 209$. Only about seven percent of post-1950 aption plans use new issue sharea which may be subjected to pre-emptive rights. NICB, Executrve STocx Owarnsnip PLA:s 11 (1951) (data on source of stock for $\$ 6$ option plans).

31. Holthusen v. Budd Mfg. Co., 52 F. Supp. 125, 127, somc, 53 F. Supp. 483,491 (E.D. Pa. 1943) (statute permitting elimination of pre-emptive rights in stod: purchase plans) ; Eliasberg v. Standard Oil Co., N.J. Super. Ct., Nov. 12, 1952 (same); Guttlieb v. Heyden Chemical Corp., 90 A.2d 660, 666-7 (Del. Sup. Ct. 1952) (amendment of corporate charter eliminates pre-emptive rights); Washingron \& Rormschird $126-9$ (collection and discussion of stock purchase statutes). Application of pre-emptive rights to stocl: ontion plans is discussed in Comment, 49 CoL. L. Kev. 232, 240 (1949); Comment, 47 31rCr. L. REv. 1179, 1185 (1949).

32. See, e.g., Clamitz v. Thatcher MIfg. Co., 158 F.2d 687, 688 (2d Cir. 1947) ; Holthusen v. Budd IIfg. Co., 53 F. Supp. 488,490 (E.D. Pa. 1943). In addition to the common law action for "overreaching," Section 16(b) of the Federal Securities Act of 1934 requires officers who dispose of stock in their company within six months after its acquisition to return their profits to the company at the instance of a private suit 48 Srns. $\$ 96$ (1934), 15 U.S.C. \$7\&p(b) (1946). See Hardee, Stocl: Options asd the Issider Trading Provisions of the Securities Act of 1934, 65 HAsv. L. Rev. 997 (1952). But since executives must hold stock for six months to qualify for $\$ 130 \mathrm{~A}$ tax benefits, the Federal Securities Act will rarely be called into play.

33. See, e.g., McQuillen v. National Cash Register Co., 112 F.2d \$77, 833 (4th Cir. 1940); Holthusen v. Budd MIfg. Co., 53 F. Supp. $48 S$ (E.D. Pa 1943). For criticism of the McQuillen decision, see Baliantine on CoRpuritions 194-5 (2d ed. 1940).

34. See, e.g., Continental Securities Co. v. Belmont, 206 N.Y. 7, 17-18, 99 N.E. 138, 142 (1912). For collection of cases see WAsHINGTON \& RorHschud 252-5. 
In the absence of legal protection, stock-option grants are excellent vehicles for invasion of stockholder interests through gifts of corporate assets and voting rights. Since there is little arm's length dealing between directors and executives, and none where directors vote their own pay, the interplay of market forces cannot insure that compensation is reasonably geared to the value of services. ${ }^{35}$ Presumably, stockholders exercise a check against "insider abuse" through the practice of ratification. ${ }^{36}$ But because the corporation has marked advantages in proxy fights, ratification is often an empty formality. ${ }^{37}$ While these conditions inhere generally in granting executive compensation, they are present in greater degree where stock options are used. Proxy statements, ostensibly designed to inform stockholders for purposes of intelligent judgment of option proposals, do little more than urge adoption of plans. ${ }^{38}$ Statments do not usually reveal the hidden diminution of corporate earnings resulting from loss of a "compensation" tax deduction when a Section $130 \mathrm{~A}$ option is granted. ${ }^{30}$ Nor do they present any attempt to set forth the basis for the valuation of executive services. ${ }^{40}$ At the same time, since the potential value of the option is hitched to future corporate prosperity, proxy statements do not assert-and stockholders cannot know -how much the executive will actually receive. ${ }^{41}$ In this situation, insiders may take full advantage of their special knowledge of corporate affairs to provide seemingly plausible rewards that later ripen into excesses. ${ }^{42}$

To protect shareholders, courts should refuse to apply the "business judgment" presumption of validity in favor of stock-option plans. Generally, use

35. Dimock and Hyde, Bureaucracy and Trustefship in Large Corporations 23-5, 124 (TNEC Monograph 11, 1940) ; Bates, The Board of Directors, 19 HARv. Bus. REv. 72, 78-9 (1940).

36. "In our view ... the entire atmosphere is freshened and a new set of rules invoked where formal approval has been given by a majority of independent, fully informed stockholders." Gottlieb v. Heyden Chemical Corp., 91 A.2d 57, 59 (Del. Sup. Ct. 1952). In fact, where stockholders' ratification is unanimous, courts will immunize plans from judicial review. See Kerbs v. California Eastern Airways, Inc., 90 A.2d 652, 656 (Del. Sup. Ct. 1952) ; Eliasberg v. Standard Oil Co., N.J. Super. Ct., Nov. 12, 1952.

37. Stockholders may not learn of plans in time to contest them effectively; incumbents have easier access to stockholder lists; management can draw on the corporate treasury for proxy fight expenses; management often rides in on sharcholder inertia. For full discussion, see Note, 61 YALE L.J. 229 (1952) and sources therein citcd.

38. NICB, Executive Stock Ownership Plans 34-72 (1951); Baker, Stock Options for Executives, 19 HARv. BUS. Rev. 106, 116 (1940).

39. NICB, op. cit. supra note 38, at 37-72 (1951) (of 25 post-1950 proxy statements examined, only four mention loss of corporate deduction).

40. Ibid.

41. Ibid.

42. For discussion of abuse of insider knowledge, see Overfield v. Pennroad Corp., 42 F. Supp. 586, 612 (E.D. Pa. 1942), rev'd, 146 F.2d 889, 924 (3d Cir. 1942) ; Hornstein, Legal Controls for Intracorporate Abuse-Present and Future, 41 CoL. L. REv. 405, 416 (1941). Apparently this danger troubled even the proponents of $\$ 130 \mathrm{~A}$. H.R. Rux. No. 2087, 80th Cong., 2nd Sess. 5-6 (1948). 
of the presumption rests on a desire to avoid judicial interference in corporate business decisions. ${ }^{43}$ However, an exception to the rule has long been recognized when a subtantial possibility of abuse of shareholder rights exists, as where transactions are not at arm's length. Thus, for example, the presumption is not applied where insiders vote themselves compensation without obtaining stockholder approval.44 But the rationale of the exception applies equally when directors vote executive compensation, for there is again little arm's length dealing. ${ }^{45}$ And since ratifications function primarily as rubber stamps, ${ }^{46}$ their occurrence can hardly correct abuses sufficiently to warrant bringing the presumption into play. Abolition of the presumption will make stockholder suits a more realistic proceeding. ${ }^{47}$ It will force corporate administrators to produce facts, peculiarly within their knowledge, of the actual objective of the option plan and the basis for their evaluation of the option and executive services. Moreover, courts will be obliged, as they are when directors vote themselves compensation without ratification, to employ their own judgment rather than hand the case to defendants whenever the court is in doubt. 48

43. See, e.g., Clamitz v. Thatcher 11fg. Co., 158 F.2d 687, 693 (2d Cir. 1947), ccrt. denied, 331 U.S. \$25 (1947); Ballantrne on Cosforntions $\$ 63 a$ (2d ed. 1946) and sources therein cited.

44. See, e.g., Schemmel v. Hill, 91 Ind. App. 373, 385, 169 N.E. 678,683 (1930); 3 Fletcher, Cyclopedia of Corporation Law \$921 (rev. ed. 1947).

45. See note 35 supra.

46. See note 37 supra.

47. For discussion of the utility of private actions to prevent and police corporate abuse, see Brindle v. Smith, 46 F. Supp. 522, 529 (S.D.N.X. 1942); Comment, 34 CoL L. REv. 1308, 1321 (1934).

48. Shortly before this issue went to press, decisions were handed down in Kaufman v. Shoenberg, 21 U.S.L. WEEK 2194 (Del. Ch. Oct. 21, 1952), and Eliasberg v. Standard Oil Co., N.J. Super. Ct., Nov. 12, 1952, the first cases applying the Easteri Airatuys and Heyden Chemical holdings. In both cases boards of directors voted stod: options to a majority of their members and to certain key employees, and subsequently secured stociholder ratification. In Kaufman the court admitted that the options were sicither secessury nor intended to retain the serices of the recipients. Nevertheless, it held two-year employment contracts sufficient consideration for the options. And although ratification was sceured without disclosing either the identity of specific recipients of the options or the fact that these recipients already benefited from a profit-sharing plan, the court refused to use its own judgment in weighing the plan's reasonableness. In Standard Uil the court ayproved an "incentive option" although it indicated that there was no danger of losing the exceutives and that they were already putfing forth their best efforts. Read together, lousfmon and Standard Oil thus make meaningless the doctrinal requirements of legitimate objectives and adequate safeguards for option plans. Additionally, Standard Oil provides two significant lessons for future litigants. Judged by the New Jersey court's reaction to the faets of the case, a corporation does well in securing SEC "approval" of its proxy statement; and complaining shareholders decidedly should attempt to demonstrate (a) that many uther shareholders were misled by the proxy statement, and (b) that these shareholders would have voted against the option plan if certain undisclosed facts had been revealed. 